\title{
Binding-, Intracellular Transport-, and Biosynthesis-defective Mutants of Vasopressin Type 2 Receptor in Patients with X-linked Nephrogenic Diabetes Insipidus
}

\author{
Hiroyasu Tsukaguchi, * Hiroaki Matsubara, ${ }^{*}$ Shigeru Taketani, ${ }^{\star}$ Yasukiyo Mori, ${ }^{*}$ Tsutomu Seido, ${ }^{\boldsymbol{\$}}$ and Mitsuo Inada* \\ * Second Department of Internal Medicine, and ${ }^{\ddagger}$ Department of Hygiene, Kansai Medical University, Moriguchi, Osaka, 570; and \\ ${ }^{\S}$ Immunobiological Laboratories, Fujioka, Gunma, 375, Japan
}

\begin{abstract}
Nephrogenic diabetes insipidus (NDI) is most often an Xlinked disorder in which urine is not concentrated due to renal resistance to arginine vasopressin. We recently identified four vasopressin type 2 receptor gene mutations in unrelated X-linked NDI families, including R143P, $\Delta$ V278, R202C, and 804insG. All these mutations reduced ligand binding activity to $<10 \%$ of the normal without affecting mRNA accumulation. To elucidate whether the receptors are expressed on the cell surface, we analyzed biosynthesis and localization of tagged or untagged receptors stably expressed in Chinese hamster ovary $(\mathrm{CHO})$ cells, using two antibodies directed against distinct termini. Whole-cell and surface labeling studies revealed that the $\mathbf{R 2 0 2 C}$ clone had both surface-localized (50-55 $\mathrm{kD}$ ) and intracellular proteins ( 40 and $75 \mathrm{kD}$ ), similar to the wild-type AVPR2 clone, whereas the R143P and $\Delta V 278$ clones lacked the surface receptors, despite relatively increased intracellular components. The 804insG mutant cell produced no proteins despite an adequate mRNA level. Immunofluorescence staining confirmed that the $\mathbf{R 2 0 2 C}$ mutant reaches the cell surface, whereas the R143P and $\Delta V 278$ mutants are retained within the cytoplasmic compartment. Thus, R202C, R143P/ $\Delta V 278$, and 804insG result in three distinct phenotypes, that is, a simple binding impairment at the cell surface, blocked intracellular transport, and ineffective biosynthesis or/and accelerated degradation of the receptor, respectively, and therefore are responsible for NDI. This phenotypic classification will help understanding of molecular pathophysiology of this disorder. (J. Clin. Invest. 1995.
\end{abstract}

Numbering of nucleotide and amino acid for the human AVPR2 used here corresponds to GenBank entry Z11687 and Birnbaumer et al. (7), respectively.

Address correspondence to Hiroaki Matsubara, M.D., Second Department of Internal Medicine, Kansai Medical University, 10-15 Fumizono, Moriguchi, Osaka 570, Japan. Phone: 6-992-1001; FAX: 6-9986178.

Received for publication 31 May 1995 and accepted in revised form 20 July 1995.

J. Clin. Invest.

(C) The American Society for Clinical Investigation, Inc.

0021-9738/95/10/2043/08 \$2.00

Volume 96, October 1995, 2043-2050
96:2043-2050.) Key words: vasopressin receptors • G-protein • diabetes insipidus • urinary concentration • mutation

\section{Introduction}

Nephrogenic diabetes insipidus (NDI) ${ }^{1}$ is a rare disorder which is characterized by failure of renal tubules to reabsorb water due to renal tubular resistance to arginine vasopressin (AVP) (1). Infant males present with clinical manifestations based upon dehydration, unexplained fever, vomiting, and failure to thrive. Persistent dehydration with hypernatremia may lead to consequent mental retardation or even death, if diagnosis and treatment are delayed. Early diagnosis and treatment to ensure an adequate intake of fluid are essential for these patients. While most cases follow an X-linked inheritance mode, autosomal forms of transmission have been described (1).

In an X-linked form of NDI, previous investigations (2-6) had shown that an arginine vasopressin type 2 receptor (AVPR2) defect could be the molecular basis for lack of concentration of the urine. After cloning of the human AVPR2 cDNA $(7,8)$, this hypothesis has been directly tested by polymerase chain reaction (PCR)-based sequencing of the gene from NDI patients. More than 60 AVPR2 gene mutations have been noted in NDI families to date, including missense mutations, small deletion/insertions, tandem duplication, large deletion and nonsense mutations leading to a truncated receptor (920). Biocnemical defects such as impaired binding affinity, capacity, adenylyl cyclase activation, and combination of the three parameters were found in several mutations, e.g., R137H and R113W (21-23). The fundamental problem of whether or not the mutant proteins are produced or expressed on the cell surface was addressed in part by Pan et al. (22), in which a NDI mutation R181C impairs ligand binding but dose not affect surface expression when tagged and expressed transiently in COS cells. However, mechanisms associated with the receptor transport or biosynthesis have remained to be tested, as a receptor-specific antibody has not been available.

We recently identified four AVPR2 mutations in unrelated Japanese kindreds with NDI including R143P, $\Delta$ V278, R202C, and 804insG leading to a carboxyl-terminal deletion. These mutations were distributed in four distinct domains of the receptor,

1. Abbreviations used in this paper: AVP, arginine vasopressin; AVPR2, arginine vasopressin type 2 receptor; $\mathrm{CHO}$, Chinese hamster ovary; NDI, nephrogenic diabetes insipidus. 
the 2nd cytoplasmic, 6th transmembrane, 3rd extracellular, and 3 rd cytoplasmic domains, respectively $(15,24)$. The latter three have been detected in other NDI families $(16,18,19)$. We previously expressed these mutations in Chinese hamster ovary (CHO) cell and analyzed their biochemical properties $(24,25)$. A R143P clone showed reduced binding capacity ( $10 \%$ of normal) but retained normal binding affinity. Moreover, the cells produced cAMP up to half the normal, suggesting that about $10 \%$ of the R143P mutant might have biologically normal functions. On the other hand, CHO cells expressing $\triangle$ V278, R202C, and 804insG had no binding activity, although these cells did produce levels of mRNA similar to the wild-type AVPR2 clone.

Considering that the four mutations greatly reduce or abolish ligand binding activity, it is speculated that the genetic errors could affect efficient receptor translation and subsequent transport to the plasma membrane. To test this possibility, we developed a new receptor-specific antiserum and analyzed localization as well as biosynthesis of the mutant receptors stably expressed in $\mathrm{CHO}$ cells. We also used an epitope tagging technique to facilitate surface localization of the receptors. Use of this strategy led to the molecular identification of the receptors with molecular masses of $40,50-55$, and $75 \mathrm{kD}$. The $50-55-\mathrm{kD}$ protein is presumably localized on the cell surface, whereas the other two masses seem to be the intracellular receptors. We showed here that there is a molecular heterogeneity of the mutants: $(a)$ binding-defective mutant that is normally sorted into the plasma membrane but loses ligand binding activity; $(b)$ transport-defective mutant that is produced but gets trapped in the intracellular organelle; and $(c)$ biosynthesis-defective mutant that is ineffectively translated into the receptor protein. The proposed classification of NDI mutations facilitates understanding of the molecular pathophysiology of NDI and pertinent therapeutic strategies can be developed.

\section{Methods}

Stable expression of tagged AVPR2 mutants. Four AVPR2 mutations were identified in unrelated Japanese families with X-linked NDI (15, 24) (Fig. 1). Cloning of a human AVPR2 cDNA and mutagenesis of the four AVPR2 mutants were described elsewhere $(24,25)$. The wildtype and mutant AVPR2 constructs were transfected into Chinese hamster ovary $(\mathrm{CHO})$ cells and the biochemical properties of stable transformants were analyzed $(24,25)$ (Table I). To facilitate the surface localization, the epitope sequence GYPYDVPDYA, derived from the influenza hemagglutinin protein $(26,27)$, was inserted between the first methionine and leucine residues in the $\mathrm{NH}_{2}$-terminal region of either wild-type and mutant AVPR2s, using polymerase chain reaction (Fig. 2). The tagged AVPR2 cDNA constructs were subcloned into the eukaryotic expression vector pMT3DSV2 and cotransfected with pSV2neo into dihydrofolate reductase deficient $\mathrm{CHO}$ cells by the calcium phosphate method (28-30). After selection in $\alpha$-minimum essential medium without deoxyribonucleosides supplemented with $10 \%$ dialyzed fetal bovine serum containing the antibiotic G418 ( $400 \mu \mathrm{g} / \mathrm{ml}$, GIBCO BRL, Gaithersburg, MD), the resistant clones were picked up and subjected to stepwise amplification with Methotrexate (50-200 nM; Sigma Chemical Co., St. Louis, MO). The expression levels of AVPR2 were screened by mRNA detection.

Northern blotting. Total RNA prepared from CHO cells $(20 \mu \mathrm{g})$ was electrophoresed on a $1.0 \%$ agarose in the presence of $20 \mathrm{mM}$ MOPS/5 mM sodium acetate/1 mM EDTA buffer ( $\mathrm{pH} 7.0)$ and $7.4 \%$ formaldehyde. The RNA was transferred overnight by capillary action using 10× SSC to nylon membrane (Pall, Glen Cove, NY) and then baked at $80^{\circ} \mathrm{C}$ for $2 \mathrm{~h}$. The membrane was hybridized overnight at $42^{\circ} \mathrm{C}$

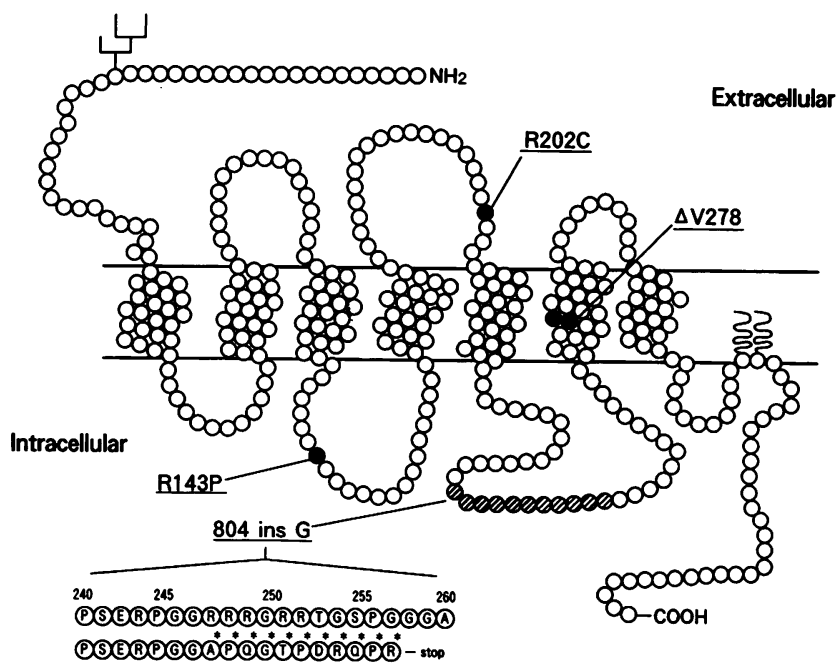

Figure 1. Locations and biochemical functions of the AVPR2 mutations. The seven putative transmembrane structures of the AVPR2 are depicted on the basis of previously reported cDNA sequence (7). The amino terminus is predicted to face the extracellular space and contains a potential N-linked glycosylation site at Asn. ${ }^{22}$ Two possible palmitoyl anchoring sites at $\mathrm{Cys}^{341.342}$ in the 4th cytoplasmic domain are also illustrated. Locations of the four mutations including R143P, $\Delta$ V278, $\mathrm{R} 202 \mathrm{C}, 804$ ins $\mathrm{G}$ are shown. The $\Delta \mathrm{V} 278$ mutation causes a single amino acid deletion of a valine residue at either position of 278 or 279 . A single G insertion, 804insG, at nucleotide 804-809 (codon 245-246) lies in the 3rd cytoplasmic domain. This mutation causes a frame shift changing amino acid sequences from codon 247 to 257 (dashed circles), eventually incorporating a stop codon at amino acid position 258 . The lower part of the figure highlights missense sequences generated by the mutation ( 11 amino acids indicated by asterisks). Nucleotide and amino acids are numbered in accordance with GenBank entry Z11687 and Birnbaumer et al. (7), respectively.

in a $40 \%$ formamide solution containing ${ }^{32} \mathrm{P}$-labeled probe of a $0.9-\mathrm{kb}$ (nucleotide 91-977) human AVPR2 cDNA $\left(1 \times 10^{6} \mathrm{cpm} / \mathrm{ml}\right)$. Blots were washed twice in $2 \times \mathrm{SSC} / 0.1 \%$ SDS at room temperature for 15 min and twice in $0.2 \times \mathrm{SSC} / 0.1 \%$ SDS at $50^{\circ} \mathrm{C}$ for $15 \mathrm{~min}$. After stripping, the blots were reprobed with $\beta$-actin cDNA, as previously reported (31).

Generation of a receptor-specific antiserum. A synthetic peptide corresponding to the carboxyl-terminal 15-amino acid residues of AVPR2 (SCTTASSSLAKDTSS, amino acid 357-371) was coupled to thyroglobulin with $\mathrm{N}-(\mathrm{m}-\mathrm{Maleimidobenzoyloxy})$ succinimide. Antisera were procured after subcutaneous injection of the preparation into a New Zealand White rabbit (32).

Cell labeling. For biosynthetic labeling, cells grown in a 60-mm dish were washed twice with methionine and cysteine-free Dulbecco's modified Eagle's medium (DME, GIBCO BRL). The cells were then incubated with the Met/Cys deficient DME containing $0.5 \mathrm{mCi} / \mathrm{dish}$ of $\left[{ }^{35} \mathrm{~S}\right] \mathrm{Met} / \mathrm{Cys}$ mixture (DuPont New England Nuclear, Boston, MA) at $37^{\circ} \mathrm{C}$ for $30 \mathrm{~min}$. For surface labeling, cells $\left(2-3 \times 10^{7}\right)$ were washed and collected in phosphate-buffered saline containing $0.02 \%$ EDTA. The cells were iodinated with Iodobeads (Pierce, Rockford, IL) and 0.5 $\mathrm{mCi}$ of $\mathrm{Na}^{125} \mathrm{I}$ (DuPont New England Nuclear) in $500 \mu \mathrm{l}$ of $10 \mathrm{mM}$

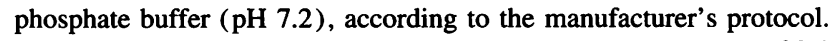

Immunoprecipitation. Cells were solubilized for $30 \mathrm{~min}$ at $4^{\circ} \mathrm{C}$ in buffer of $50 \mathrm{mM}$ Tris- $\mathrm{HCl} \mathrm{pH} 8.0,150 \mathrm{mM} \mathrm{NaCl}, 1 \mathrm{mM}$ EDTA, $1 \%$ Triton $\mathrm{X}-100,0.1 \%$ SDS containing $0.1 \mathrm{mM}$ phenylmethylsulfonyl fluoride, $100 \mu \mathrm{g} / \mathrm{ml}$ bacitracin, $10 \mathrm{U} / \mathrm{ml}$ aprotinin, and $5 \mu \mathrm{g} / \mathrm{ml}$ leupeptin. After removal of insoluble material by centrifugation, the lysates were precleared at $4^{\circ} \mathrm{C}$ for $30 \mathrm{~min}$ and then immunoprecipitated with 


\begin{tabular}{|c|c|c|c|c|c|c|}
\hline \multirow[b]{2}{*}{ Mutation } & \multirow[b]{2}{*}{ Type } & \multirow[b]{2}{*}{ Nucleotide* change } & \multirow[b]{2}{*}{ Location ${ }^{\ddagger}$} & \multicolumn{2}{|c|}{ Binding property } & \multirow[b]{2}{*}{$\begin{array}{c}\text { cAMP accumulation" } \\
\left(\mathrm{pmol} / \mathrm{receptor} \times 10^{-8}\right)\end{array}$} \\
\hline & & & & $\begin{array}{c}B_{\max } \\
(\mathrm{fmol} / \mathrm{mg})\end{array}$ & $\begin{array}{c}K_{\mathrm{d}} \\
(\mathrm{nM})\end{array}$ & \\
\hline R143P & Missense & $\mathrm{G} \rightarrow \mathrm{C}$ at 499 & C II & $232 \pm 46$ & $1.7 \pm 0.4$ & $3.2 \pm 0.5$ \\
\hline$\Delta \mathrm{V} 278$ & Amino acid deletion & Deletion 3bp (903-908) & TM VI & - & - & - \\
\hline R202C & Missense & $\mathrm{C} \rightarrow \mathrm{T}$ at 675 & E III & - & - & ND \\
\hline 804insG & Frame shift $\sim$ premature termination & Insertion of $G(804-809)$ & C III & - & - & ND \\
\hline
\end{tabular}

* Nucleotide is numbered according to the sequence numbering of GenBank entry Z11687. ${ }^{\ddagger}$ Extracellular (E), cytoplasmic (C), and transmembrane (TM) domains are assigned by the proposed topology of the AVPR2 (7). ${ }^{8}$ Data are indicated by mean $\pm \operatorname{SE}(n=3)$. Details of binding assay were described previously $(24,25) . B_{\max }$ and $K_{\mathrm{d}}$ values of the wild-type AVPR2 expressing CHO cell are $1890 \pm 110 \mathrm{fmol} / \mathrm{mg}$ and $1.6 \pm 0.5 \mathrm{nM}(n=4)$, respectively. - , undetectable. "Data are indicated by mean $\pm \mathrm{SE}(\mathrm{n}=12)$. Details of cAMP assay were described previously $(25)$. Accumulation of cAMP in the wild-type AVPR2 expressing CHO cell is $6.7 \pm 0.9$ pmol/receptor $\times 10^{-8}(n=16)$. - , undetectable; $N D$, not determined.

A

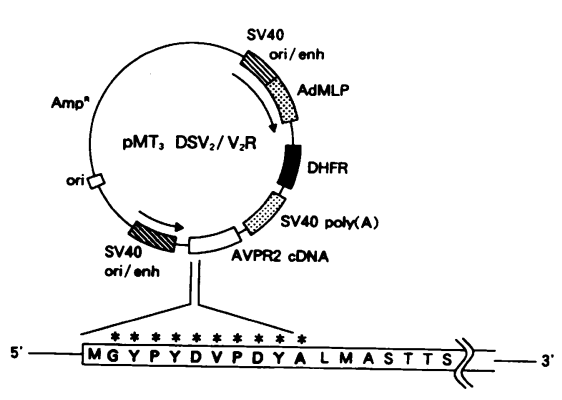

B

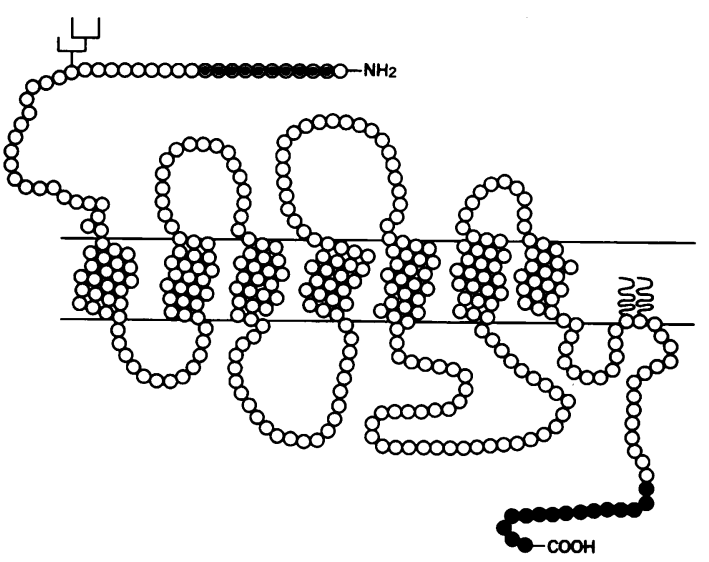

Figure 2. Construction of a vector for stable expression of tagged AVPR2 and recognition sites of the antibodies. $(A)$ The epitope sequence GYPYDVPDYA (shown by asterisks) is introduced between the first methionine and leucine residues in the $\mathrm{NH}_{2}$ terminus of the receptor. Open box indicates the coding region of the AVPR2 gene. The tagged AVPR2 cDNA constructs were subcloned into the pMT3DSV2 vector in counterclockwise direction at the EcoRV site with blunt-end ligation. This vector is used for stable expression in dihydrofolate reductase deficient $\mathrm{CHO}$ cells and contains the mouse dihydrofolate reductase (DHFR) gene under transcriptional regulation of the adenovirus major late promoter (AdMLP) and SV40 enhancer $(28,29)$. (B) The 12CA5 monoclonal antibody and rabbit polyclonal antiserum are directed against the 12CA5 epitope (dot circle) in the Nterminus and 15 amino acids in the carboxyl tail of the receptor (closed circle), respectively. either $5 \mu \mathrm{g} / \mathrm{ml}$ of $12 \mathrm{CA} 5$ monoclonal antibody (Boehringer Mannheim, Indianapolis, IN) or $3 \mu \mathrm{l}$ of rabbit polyclonal antiserum raised against the carboxyl-terminal portion of AVPR2. After a $1 \mathrm{~h}$ incubation at room temperature, the immunoprecipitates were sedimented with a $10 \%$ slurry of protein A-sepharose (Sigma Chemical Co., St. Louis, MO) and washed three times with high salt buffer $(50 \mathrm{mM}$ Tris- $\mathrm{HCl} \mathrm{pH} 8.0,0.5$ $\mathrm{M} \mathrm{NaCl}, 1 \mathrm{mM}$ EDTA, $0.1 \%$ SDS, $0.5 \%$ Triton X-100) and low salt buffer ( $50 \mathrm{mM}$ Tris-HCl pH 7.4, 1 mM EDTA, $0.1 \%$ SDS, $0.5 \%$ Triton $\mathrm{X}-100$ ). The samples were dissociated by heating for $2 \min$ in 1 $\times$ Laemmli's sample buffer and analyzed by $10 \%$ SDS-polyacrylamide electrophoresis.

Immunofluorescence. Immunocytochemical studies were done according to Masaki et al. (33). Briefly, CHO cells expressing wild-type and four mutants of the $\mathrm{NH}_{2}$-terminal tagged AVPR2s were grown on glass coverslips and fixed at room temperature for $20 \mathrm{~min}$ in $4 \%$ paraformaldehyde in phosphate-buffered saline (PBS). For permeabilization, cells were treated with PBS containing $0.1 \%$ Triton X-100. After incubation in a blocking buffer containing $2 \%$ fetal calf serum in PBS, specimens were incubated at $37^{\circ} \mathrm{C}$ for $40 \mathrm{~min}$ with the $12 \mathrm{CA} 5$ monoclonal antibody diluted by the blocking buffer to $5 \mu \mathrm{g} / \mathrm{ml}$. Bound antibody was stained with a secondary antibody of goat antimouse rhodamine conjugate (Protos Immunoresearch, San Francisco, CA) at 1/100 dilution. The coverslips were examined and photographed under a fluorescent microscope BH-2 (Olympus Corp., Tokyo, Japan).

\section{Results}

Detection of tagged AVPR2 by immunoprecipitation. We first examined biosynthesis and localization of epitope-tagged AVPR2 in CHO cells. Preliminary studies showed that introduction of the 12CA5 epitope into the amino terminal region of AVPR2 did not perturb ligand binding property of the receptor with $K_{\mathrm{d}}=1.3 \pm 0.4 \mathrm{nM}$ and $B_{\max }=2100 \pm 340 \mathrm{fmol} / \mathrm{mg}$ (mean $\pm \mathrm{SE}, n=3$ ), compared with that of the native receptor $(24,25)$. We cloned several colonies of $\mathrm{CHO}$ cells expressing epitope-tagged either wild-type or mutant AVPR2s (R143P, $\Delta$ V278, R202C, and 804insG) and screened receptor mRNA accumulation by Northern blotting. As shown in Fig. 3, tagged wild-type and mutant receptor expressing cells produced almost equivalent levels of AVPR2 mRNA.

We chose these stable transformants for further analysis regarding the biosynthesis of receptor protein. The biosythetic labeling study on tagged wild-type AVPR2 expressing CHO cells followed by immunoprecipitation with 12CA5 antibody showed that the clone produced two bands at 40 and $75 \mathrm{kD}$ 

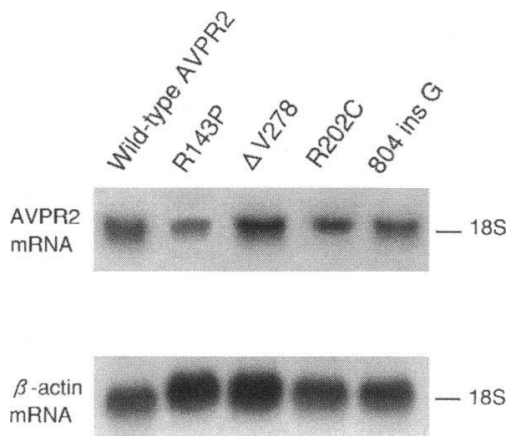

Figure 3. Northern blot analysis of receptor mRNA in CHO cells. Total RNA ( $20 \mu \mathrm{g})$ isolated from $\mathrm{CHO}$ cells expressing tagged AVPR2 was electrophoresed on $1.0 \%$ agarose gel and transferred to a nylon membrane. The blots were hybridized with a $\left[{ }^{32} \mathrm{P}\right] \mathrm{dCT}$-labeled 0.9 $\mathrm{kb}$ receptor cDNA probe (upper panel), indicating that the wild-type and four mutant AVPR2 cell lines produced comparable amounts of receptor mRNA. The same blot was then stripped and rehybridized with a $\beta$-actin probe (lower panel) to confirm that equal amounts of mRNA had been loaded onto each lane.

(Fig. 4). Molecular weight of the 40-kD band was consistent with that calculated for the protein core of the cloned AVPR2 $\left(M_{\mathrm{r}} 40,285\right)(7)$, whereas the $75-\mathrm{kD}$ mass presumably reflected the different degrees of glycosylation. These bands were absent in untransfected control $\mathrm{CHO}$ cells and were completely absorbed by a competitive assay in the presence of $100 \mu \mathrm{M} 12 \mathrm{CA} 5$ peptide, indicating that the two molecular masses are specifically recognized by the $12 \mathrm{CA} 5$ monoclonal antibody. Molecular weights of the receptors were fairly consistent with those of reported by Pan et al. (22), in which tagged AVPR2s transiently expressed in COS cells were visualized as broad bands right below 43 or $69 \mathrm{kD}$. Three mutant cell lines (R143P, $\Delta$ V278, and R202C) had the two bands similar to those of the wildtype receptor clone. The relative low density of the receptor proteins for the R202C mutant may be due to a slightly lower level of the receptor mRNA accumulation in the R202C mutant cell (Fig. 3). On the other hand, the 804insG cell line showed

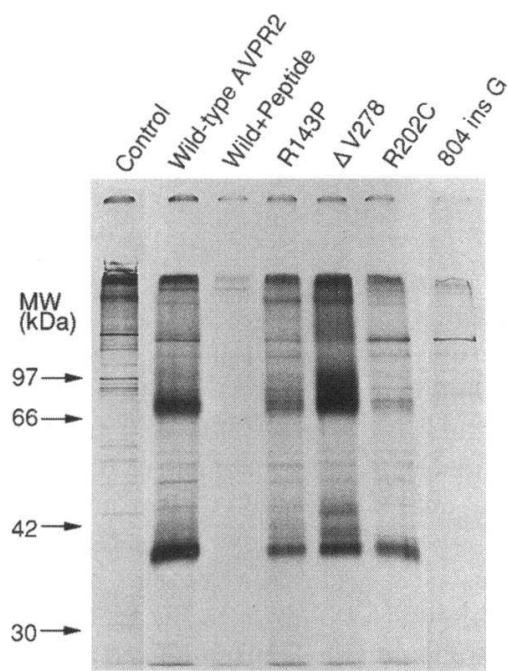

Figure 4. Immunoprecipitation of biosynthetic-labeled $\mathrm{CHO}$ cells expressing tagged AVPR2. CHO cells expressing tagged either wild-type or mutant (R143P, $\Delta$ V278 R202C, and 804insG) AVPR2s grown in a 60mm dish were metabolically labeled with 0.5 $\mathrm{mCi}$ per dish of $\left[{ }^{35} \mathrm{~S}\right]-$ Met/Cys mixture at $37^{\circ} \mathrm{C}$ for $30 \mathrm{~min}$. After lysis, equivalent amounts of the labeled receptors $(1-$ $\left.2 \times 10^{7} \mathrm{cpm}\right)$ were immunoprecipitated with the 12CA5 antibody di-

rected against the engineered epitope-tag at the $\mathrm{NH}_{2}$ terminus of the receptor. Control (untransfected) $\mathrm{CHO}$ cells were also examined in a similar condition. For the peptide blocking experiment, labeled wildtype receptors were immunoprecipitated in the presence of $100 \mu \mathrm{M}$ 12CA5 peptide. The samples were analyzed by a $10 \%$ SDS-PAGE and fluorography.

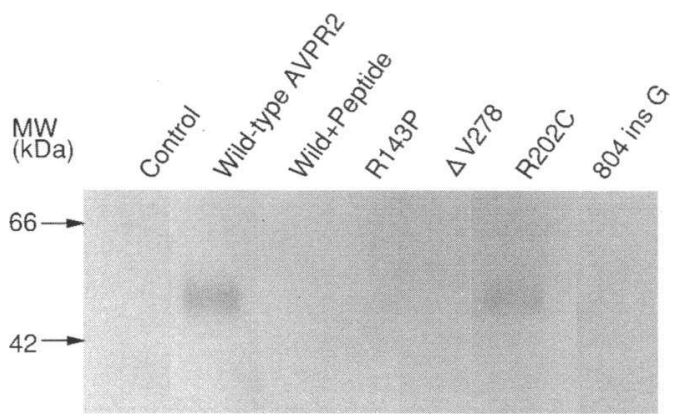

Figure 5. Detection of surface receptors in $\mathrm{CHO}$ cells expressing tagged AVPR2. Surface proteins of CHO cells expressing tagged either wildtype or mutant (R143P, $\triangle$ V278, R202C, and 804insG) AVPR2s were labeled with $0.5 \mathrm{mCi} \mathrm{Na}{ }^{125} \mathrm{I}$. After lysis, the iodinated cell surface proteins $\left(1-2 \times 10^{7} \mathrm{cpm}\right)$ were immunoprecipitated with the 12CA5 antibody. Control (untransfected) $\mathrm{CHO}$ cells were also examined in a similar condition. For the competition assay, labeled wild-type receptors were immunoprecipitated in the presence of $100 \mu \mathrm{M} 12 \mathrm{CA} 5$ peptide. The samples were analyzed by a $10 \%$ SDS-PAGE.

no detectable bands, although the clone did produce levels of receptor mRNA comparable to those for the wild-type receptor cell line (Fig. 3).

Cell surface iodination of the tagged wild-type AVPR2 clone revealed $\sim 50-55-\mathrm{kD}$ band (Fig. 5), which was undetectable in the metabolic labeling experiments with the same antibody. The $50-55-\mathrm{kD}$ protein was absent in untransfected control CHO cells and was completely absorbed by a competitive assay in the presence of $100 \mu \mathrm{M} 12 \mathrm{CA} 5$ peptide, indicating that the molecular mass is specifically recognized by the 12CA5 monoclonal antibody. This putative cell surface receptor protein was found in the R202C clone but not in the R143P, $\Delta V 278$, and 804insG mutant cell lines, suggesting that latter three mutants are absent on the cell surface. At least two other clonal cell lines of the respective mutations gave similar results, thereby excluding the possibility that differences were caused by a clonal variation.

Detection of untagged AVPR2 by immunoprecipitation with polyclonal antiserum. To characterize the AVPR2 mutants in greater detail, we examined the localization and biosynthesis, using untagged AVPR2 mutant expressing $\mathrm{CHO}$ cells and polyclonal antiserum directed toward the carboxyl-terminal portion of the receptor. These cell lines, expressing levels of mRNA similar to the wild-type AVPR2 clone, were previously established and analyzed in terms of biochemical properties $(24,25)$ (Table I). Use of the polyclonal antiserum has some advantage in that the antibodies may provide more versatile reactivity than a monoclonal antibody, thereby improving sensitivity of the immunodetection. Moreover, this approach can eliminate artifacts that may be caused by engineering an epitope-tag of the receptor. Biosynthetic labeling followed by immunoprecipitation with the polyclonal antiserum showed that the untagged wild-type AVPR2 cell produced three bands of 40, 50-55, and $75 \mathrm{kD}$ (Fig. 6). The three bands were not found in untransfected CHO cells and were inhibited by a competitive assay in the presence of $100 \mu \mathrm{M}$ of the peptide immunogen, indicating specific recognition by the antiserum. The molecular weights of the upper and lower bands were compatible with those detected by immunoprecipitation of biosynthetic-labeled tagged AVPR2 


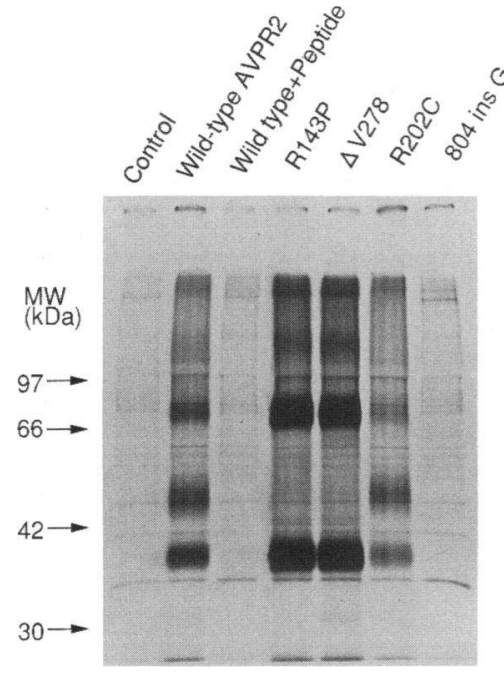

Figure 6. Immunoprecipitation of biosynthetic labeled CHO cells expressing untagged AVPR2 with a receptor specific antiserum. $\mathrm{CHO}$ cells expressing untagged either wild-type or mutant (R143P, $\triangle \mathrm{V} 278, \mathrm{R} 202 \mathrm{C}$, and 804insG) AVPR2s grown in a $60-\mathrm{mm}$ dish were metabolically labeled with $0.5 \mathrm{mCi}$ per dish of $\left[{ }^{35} \mathrm{~S}\right] \mathrm{Met} / \mathrm{Cys}$ mixture at $37^{\circ} \mathrm{C}$ for 30 min. After solubilization, the labeled receptors $(1-$ $\left.2 \times 10^{7} \mathrm{cpm}\right)$ were immunoprecipitated with

rabbit polyclonal antibody raised against the carboxyl-terminal portion of AVPR2. Control (untransfected) CHO cells were also examined in a similar condition. For the peptide blocking experiment, labeled wildtype receptors were immunoprecipitated in the presence of $100 \mu \mathrm{M}$ peptide immunogen. The samples were analyzed by a $10 \%$ SDS-PAGE and fluorography.

clones with monoclonal 12CA5 antibody. The size of the middle band corresponded to that detected by immunoprecipitation of the iodinated cell-surface protein with 12CA5 antibody, suggesting that this band represents surface-localized receptors. However, cell-surface labeling experiments with the polyclonal antiserum revealed no receptor (data not shown). The failure to detect surface proteins probably resulted from the fact that untagged AVPR2 contains only one exofacial tyrosine residue that is a prerequisite for iodination, in contrast to three more tyrosine residues engineered in tagged receptor. One of the AVPR2 mutants, a R202C cell line, showed evidence of species similar to the wild-type AVPR2 expressing cell. On the other hand, R143P and $\Delta V 278$ cell lines displayed more pronounced bands at the 40 and $75 \mathrm{kD}$ but lacked the $50-55-\mathrm{kD}$ protein, and 804insG clone exhibited no detectable bands.

Immunofluorescence localization of tagged AVPR2 in CHO cells. We next tried to examine immunocytochemical localization of the AVPR2 mutants to ask if the mutants are expressed on the cell surface. For this purpose, we chose tagged AVPR2 expressing $\mathrm{CHO}$ cells, because the monoclonal antibody provided a more specific staining than did the polyclonal antiserum. We first stained nonpermeabilized cells with the 12CA5 antibody directed against exofacial epitope-tag in the $\mathrm{NH}_{2}$ terminus of the receptor. Untransfected control cells were not detectably stained by the antibody (data not shown). As shown in Fig. 7 $A$, apparent surface fluorescence was visualized in tagged wildtype and R202C mutant clones. In contrast, R143P and $\Delta$ V278 cell lines lacked the surface signal. Under conditions of permeabilization, both wild-type and mutant (R143P, $\Delta$ V278, and $\mathrm{R} 202 \mathrm{C}$ ) cells showed considerable fluorescence in the perinuclear region (Fig. $7 \mathrm{~B}$ ). Because of the bright staining, we could not determine if the protein accumulated only in the endoplasmic reticulum or was distributed simultaneously in the Golgi complex. However, apparent intracellular staining with the lack of surface signal for the R143P and $\Delta$ V278 mutant cells sup- ported the notion that these mutants are indeed retained within the intracellular compartments, which were compatible with the findings of the immunoprecipitation experiments (Figs. 4-6).

\section{Discussion}

The present study provides evidence that heterogeneous molecular defects of AVPR2 are associated with NDI. We used an exofacial epitope-tagging technique that facilitates surface localization of the receptors. The specificity of our analysis was verified by findings that two antibodies directed against the distinct terminal portions of the AVPR2, (i.e., 12CA5 antibody and polyclonal antiserum recognize amino- and carboxyl-termini, respectively), detected the same molecular masses. Using the two antibodies, we identified a molecular mass of the surface-localized receptor which was not found in the Western blotting experiment with epitope tagging AVPR2 (22). The molecular size of the surface receptor $(50-55 \mathrm{kD})$ is fairly compatible with that predicted from chemical cross-linking studies ( $60 \mathrm{kD}$ ) (34). However, it should be noted that the 50 $55-\mathrm{kD}$ protein was detected in the surface iodination experiments using 12CA5 antibody, whereas the putative surface component was not visualized in the biosynthetic labeling study using the same antibody. On the other hand, the 50-55-kD species were clearly evident when we immunoprecipitated the labeled whole-cell proteins with the polyclonal antiserum. One explanation for this difference is that the surface receptors may be poorly recognized by the $12 \mathrm{CA} 5$ antibody. Considering that the epitope is engineered near the putative glycosylation site of the $\mathrm{NH}_{2}$ terminus, it is possible that the bulky complex carbohydrate of the $50-55-\mathrm{kD}$ protein structurally hinders the epitope, thereby preventing the immunorecognition. Nevertheless, this problem was overcome by analyzing both surface- and biosynthetic-labeled proteins and concomitant use of a receptor-specific polyclonal antiserum.

We showed that AVPR2 mutations can be classified into at least three distinct phenotypes. The first type is observed in a R202C mutant which reaches the cell surface but loses binding activity. This characteristic was noted in another mutation of a R181C, similarly creating a new cysteine residue in the third extracellular domain (22). The results suggest that these mutations do not affect surface expression of the receptor and fail to achieve a proper conformation to access the ligand at the plasma membrane. A possible explanation is that a new extracellular cysteine residue might form de novo disulfide bonds, thereby preventing the protein from folding correctly for ligand binding (35). The second phenotype is a transport-deficient mutant, as found in a R143P and $\Delta$ V278 mutants. Radioiodineand immunofluorescence labeling of tagged R143P and $\Delta V 278$ mutants indicated their absence on the cell surface. The mutants accumulated in the intracellular compartment (i.e., 40 and 75 $\mathrm{kD}$ ) as seen in the biosynthetic labeling study with polyclonal antiserum. Such an altered intracellular distribution would account for the impaired ligand binding of the receptors. Although a ligand binding study with the R143P clone indicated that a small population $(\sim 10 \%)$ of the R143P mutants is transported to the cell surface, the expression level of surface localized receptors might be below the sensitivity of immunodetection and the surface subset not be visualized. Immunofluorescence staining of permeabilized cells expressing tagged R143P and $\Delta$ V278 mutants suggested that the mutants are predominantly 

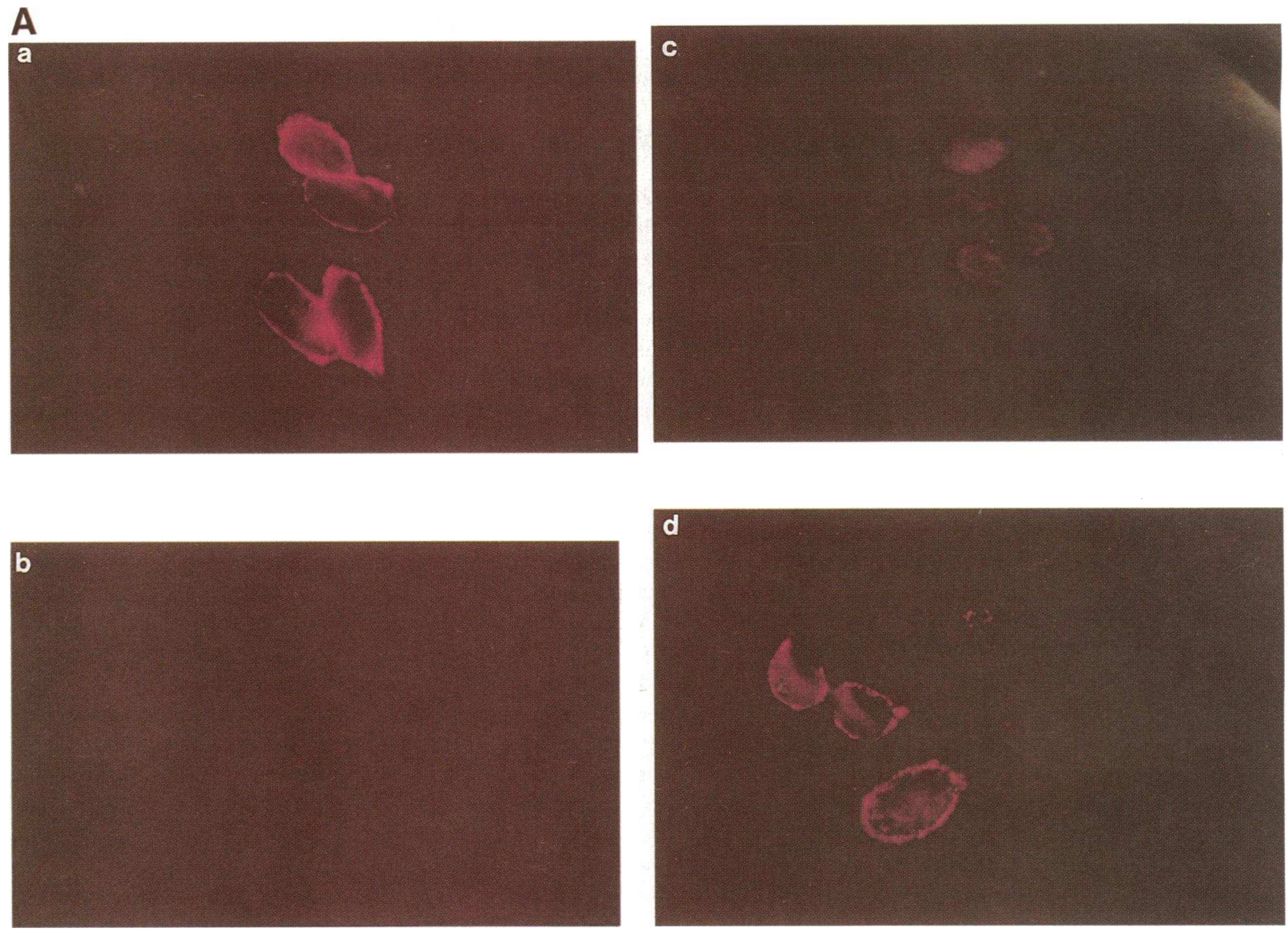

B

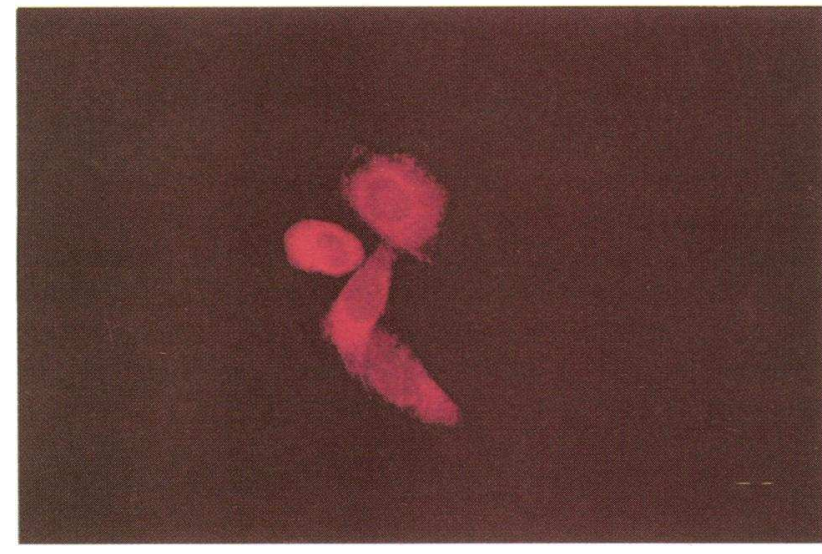

Figure 7. Immunofluorescent staining of $\mathrm{CHO}$ cells expressing tagged AVPR2. ( $A$ ) Detection of tagged receptors on the cell surface. CHO cells expressing the epitope-tagged either wild-type or mutant (R143P, $\Delta$ V278, and R202C) AVPR2s were plated on glass slips and fixed in $4 \%$ paraformaldehyde. After blocking, fixed cells under nonpermeabilized condition were incubated with 12CA5 antibody, followed by detection of rhodamine conjugated antimouse antibody. ( $a$ ) $\mathrm{CHO}$ cells expressing tagged wild-type AVPR2, (b) R143P, (c) $\Delta$ V278, (d) R202C. (B) Subcellular distribution of tagged receptors. After permeabilization with $0.1 \%$ Triton X-100, CHO cells expressing epitope-tagged wild-type receptors were stained with the same antibodies. The mutant receptor expressing (R143P, $\Delta V 278$, and R202C) cell lines showed the staining pattern essentially similar to that of the wild-type receptor expressing cell (data not shown).

retained within the endoplasmic reticulum, but strong staining prevented identification of the definite localization of the receptors. The site of blockage in transport may be identified by immunocytochemical approaches such as double-staining or electron microscopy, as was done for other naturally occurring transport-deficient mutants of plasma membrane receptors such as low density lipoprotein (LDL) receptor or rhodopsin (3639 ). Finally, we found that a truncated form of the 804insG mutant protein, devoid of one third of the carboxyl terminus, was not produced. Since the mRNA level of 804insG clone was comparable to that of the wild-type AVPR2 clone, it is likely that the mutation could interfere with the posttranscriptional process, thereby leading to ineffective translation and/or rapid degradation. Although it is unclear why the carboxyl-terminal deletion leads to such a defect, it is speculated that the carboxylterminal parts of AVPR2 might contain an important signal for receptor biosynthesis. Further study of deletion mutants removing the carboxyl tail at various sites would define the region that is essential for stable and efficient translation of the receptor.

It should be noted that expression studies have been done by using different expression systems, e.g., COS, $\mathrm{CHO}$, and murine L cells (21-25). Previous observations showed that 
function properties of the mutants somewhat differ in the transient and stable forms, suggesting that COS cells may transiently express receptors even beyond physiological levels and mask natural aspects of the mutants $(23,24)$. Since the phenotype of the R181C mutant transiently expressed in COS cells (22) fell under the category identical with the R202C mutant stably expressed in CHO cells, it is highly likely that a new cysteine incorporation in the third extracellular domain does not affect receptor transport. In this way, a specific role of the receptor subdomain in the protein function and expression should be assessed by analyzing the same or nearby mutations with different vector-host cell systems. Ideally, natural effects of the mutations could be obtained from the expression study in the corresponding collecting duct cells, but there is no available culture cell system. Further study using gene transfer or transgenic mice would be useful to confirm the results of the present experiments. This approach may allow the elucidation of a new type of the defect that is related to a receptor targeting to the correct surface of the polarized epithelial cells.

We propose a new phenotypic classification of AVPR2 mutants. Despite the genetic information available for this disorder, the biological effects have been elucidated in only a limited number of the AVPR2 mutations. Our strategy for a phenotypic classification would be used as a powerful tool to address the fundamental problem of this disease, whether or not the mutant receptors are on the cell surface. The elucidation of the receptor localization will much broaden the knowledge of the structural and function relationship of the receptor. For example, a ligandbinding defective mutant which was formerly determined by a biochemical analysis could be further divided into distinct subtypes of a simple binding-, or intracellular transport-, or biosynthesis-defective mutant. Such information should lead to improve therapy for NDI. A defect due to pure binding problem as found in a R202C mutation could be overcome by correcting the signaling pathway, using a newly designed receptor-agonist.

\section{Acknowledgments}

We are grateful to Drs. Tokihisa Kimura (Tohoku University), Sekoiya Aritaki (Tokyo Medical College), Haruka Sasaki (Fukuoka University), and Tomonobu Hasegawa (Kiyose Children's Hospital) for referring the patients. We also thank Drs. R. Masaki, T. Doi, Y. Yoshimasa, and $M$. Ohara for technical advice and discussion.

This study was supported in part by Research Grants from the Ministry of Education, Science and Culture of Japan.

\section{References}

1. Reeves, W. B., and T. E. Andreoli. 1989. Nephrogenic diabetes insipidus In The Metabolic Basis of Inherited Disease. 6th ed. C. R. Scriver, A. L. Beaudet W. S. Sly, and D. Valle. editors. McGraw-Hill, New York. 1985-2011.

2. Bichet, D. G., M. Razi, M. Lonergan, M. F. Arthus, V. Papukna, C. Kortas, and J. N. Barjon. 1988. Hemodynamic and coagulation responses to 1-desamino [8-D-arginine] vasopressin in patients with congenital nephrogenic diabetes insipidus. N. Engl. J. Med. 318:881-887.

3. Bichet, D. G., M. Razi, M. F. Arthus, M. Lonergan, P. Tittley, R. K. Smiley, G. Rock, and D. J. Hirsch. 1989. Epinephrine and dDAVP administration in patients with congenital nephrogenic diabetes insipidus. Kidney Int. 36:859-866

4. Bichet, D. G., G. N. Hendy, M. Lonergan, M. F. Arthus, S. Ligier, Z. Pausova, R. Kluge, H. Zingg, P. Saenger, E. Oppenheimer, D. J. Hirsch, S Gilgenkrantz, J. P. Salles, I. Oberle, J. L. Mandel, M. C. Gregory, T. M. Fujiwara K. Morgan, and C. R. Scriver. 1992. X-linked nephrogenic diabetes insipidus: from the ship Hopewell to RFLP studies. Am. J. Hum. Genet. 51:1089-1102.

5. van den Ouweland, A. M., M. T. Knoop, V. V. Knoers, P. W. Markslag, M. Rocchi, S. T. Warren, H. H. Ropers, F. Fahrenholz, L. A. Monnens, and B. A. van Oost. 1992. Colocalization of the gene for nephrogenic diabetes insipidus (DIR) and the vasopressin type 2 receptor gene (AVPR2) in the Xq28 region. Genomics. 13:1350-1352.

6. Jans, D. A., B. A. van Oost, H. H. Ropers, and F. Fahrenholz. 1990. Derivatives of somatic cell hybrids which carry the human gene locus for nephrogenic diabetes insipidus (NDI) express functional vasopressin renal V2-type receptors. J. Biol. Chem. 265:15379-15382.

7. Birnbaumer, M., A. Seibold, S. Gilbert, M. Ishido, C. Barberis, A. Antaramian, P. Brabet, and W. Rosenthal. 1992. Molecular cloning of the receptor for human antidiuretic hormone. Nature (Lond.). 357:333-335.

8. Seibold, A., P. Brabet, W. Rosenthal, and M. Birnbaumer. 1992. Structure and chromosomal localization of the human antidiuretic hormone receptor gene. Am. J. Hum. Genet. 51:1078-1083.

9. Rosenthal, W. A. Seibold, A Antaramian, M. Lonergan, M. F. Arthus, G. N. Hendy, M. Birnbaumer, and D. G. Bichet. 1992. Molecular identification of the gene responsible for congenital nephrogenic diabetes insipidus. Nature (Lond.). 359:233-235

10. van den Ouweland, A. M. J. C. Dreesen, M. Verdijk, N. V. Knoers, L. A. Monnens, M. Rocchi, and B. A. van Oost. 1992. Mutations in the vasopressin type 2 receptor gene (AVPR2) associated with nephrogenic diabetes insipidus. Nature Genet. 2:99-102.

11. Pan Y., A. Metzenberg, S. Das, B. Jing, and J. Gitschier. 1992. Mutations in the V2 vasopressin receptor gene are associated with X-linked nephrogenic diabetes insipidus. Nature Genet. 2:103-106.

12. Holtzman, E. J., H. W. Harris, L. F. Kolakowski, L. M. Guay-Woodford, B. Botelho, and D. A. Ausiello. 1993. A molecular defect in the vasopressin V2 receptor gene causing nephrogenic diabetes insipidus. N. Engl. J. Med. 328:15341537.

13. Merendino, J. J., A. M. Spiegel, J. D. Crawford, A. M. O'Carroll, M. J. Brownstein, and S. J. Lolait. 1993. A mutation in the vasopressin V2 receptor gene in a kindred with X-linked nephrogenic diabetes insipidus. N. Engl. J. Med. 328:1538-1541

14. Bichet, D. G., M. F. Arthus, M. Lonergan, G. N. Hendy, A. J. Paradis, T. M. Fujiwara, K. Morgan, M. C. Gregory, W. Rosenthal, A. Didwania, A. Antaramian, and M. Birnbaumer. 1993. X-linked nephrogenic diabetes insipidus mutations in North America and the Hopewell hypothesis. J. Clin. Invest. 92:1262-1268

15. Tsukaguchi, H., H. Matsubara, S. Aritaki, T. Kimura, S. Abe, and M. Inada. 1993. Two novel mutations in the vasopressin V2 receptor gene in unrelated Japanese kindreds with nephrogenic diabetes insipidus. Biochem. Biophys. Res. Commun. 197:1000-1010

16. Bichet, D. G., M. Birnbaumer, M. Lonergan, M. F. Arthus, W. Rosenthal, P. Goodyer, H. Nivet, S. Benoit, P. Giampietro, S. Simonetti, A. Fish, C. B. Whitley, P. Jaeger, J. Gertner, M. New, F. J. DiBona, B. S. Kaplan, G. L. Robertson, G. N. Hendy, T. M. Fujiwara, and K. Morgan. 1994. Nature and recurrence of AVPR2 mutations in X-linked nephrogenic diabetes insipidus. Am. J. Hum. Genet. 55:278-286.

17. Wildin, R. S., M. J. Antush, R. L. Bennett, J. M. Schoof, and C. R. Scott. 1994. Heterogeneous AVPR2 gene mutations in congenital nephrogenic diabetes insipidus. Am. J. Hum. Genet. 55:266-277.

18. Wenkert, D., J. J. Merendino, A. Shenker, N. Thambi, G. L. Robertson, A. M. Moses, and A. M. Spiegel. 1994. Novel mutations in the V2 vasopressin receptor gene of patients with X-linked nephrogenic diabetes insipidus. Hum. Mol. Genet. 3:1429-1430.

19. Faa, V., M. L. Ventruto, S. Loche, M. Bozzola, R. Podda, A. Cao, and M. C. Rosatelli. 1994. Mutations in the vasopressin V2 receptor gene in three families of Italian descent with nephrogenic diabetes insipidus. Hum. Mol. Genet. $3: 1685-1686$

20. Knoers, N. V., A. M. van den Ouweland, M. Verdijk, L. A. Monnens, and B. A. van Oost. 1994. Inheritance of mutations in the V2 receptor gene in thirteen families with nephrogenic diabetes insipidus. Kidney Int. 46:170-176.

21. Rosenthal, W., A. Antaramian, S. Gilbert, and M. Birnbaumer. 1993. Nephrogenic diabetes insipidus. A V2 vasopressin receptor unable to stimulate adenylyl cyclase. J. Biol. Chem. 268:13030-13033.

22. Pan, Y., P. Wilson, and J. Gitschier. 1994. The effect of eight V2 vasopressin receptor mutations on stimulation of adenylyl cyclase and binding to vasopressin. J. Biol. Chem. 269:31933-31937.

23. Birnbaumer, M., S. Gilbert, and W. Rosenthal. 1994. An extracellular congenital nephrogenic diabetes insipidus mutation of the vasopressin receptor reduces cell surface expression, affinity for ligand and coupling to the Gs/adenylyl cyclase system. Mol. Endocrinol. 8:886-894.

24. Tsukaguchi, H., H. Matsubara, and M. Inada. 1995. Expression studies of two vasopressin V2 receptor gene mutations R202C and 804insG in nephrogenic diabetes insipidus. Kidney Int. 48:554-562.

25. Tsukaguchi, H., H. Matsubara, Y. Mori, Y. Yoshimasa, T. Yoshimasa, K. Nakao, and M. Inada. 1995. Two vasopressin type 2 receptor gene mutations $\mathrm{R} 143 \mathrm{P}$ and $\Delta \mathrm{V} 278$ in patients with nephrogenic diabetes insipidus impair ligand binding of the receptor. Biochem. Biophys. Res. Commun. 211:967-977. 
26. Wilson, I. A., H. L. Niman, R. A. Houghten, A. R. Cherenson, M. L. Connolly, and R. A. Lerner. 1984. The structure of an antigenic determinant in a protein. Cell. 37:767-778.

27. von Zastraw, M., R. Link, D. Daunt, G. Barsh, and B. Kobilka. 1993. Subtype-specific differences in the intracellular sorting of $G$ protein-coupled receptors. J. Biol. Chem. 268:763-766.

28. Yoshimasa, Y., J. I. Paul, J. Whittaker, and D. F. Steiner. 1991. Effects of amino acid replacements within the tetrabasic cleavage site on the processing of the human insulin receptor precursor expressed in Chinese hamster ovary cells. J. Biol. Chem. 265:17230-17237.

29. Kaufman, R. J. 1990. Selection and coamplification of heterologous genes in mammalian cells. Methods Enzymol. 185:537-566.

30. Sambrook, J., E. F. Fritsch, and T. Maniatis. 1989. Molecular Cloning: A Laboratory Manual. 2nd ed. Cold Spring Harbor Laboratory Press, Cold Spring Harbor, NY.

31. Matsubara, H., I. Yamamoto, Y. Hirata, Y. Mori, and M. Inada. 1990. Changes in atrial natriuretic factor and its messenger RNA with development and regression of cardiac hypertrophy in renovascular hypertension rats. Circ. Res. 66:176-184

32. Harlow, E., and D. Lane. 1988. Antibody, A Laboratory Manual. Cold Spring Harbor Laboratory Press, Cold Spring Harbor, NY.
33. Masaki, R., A. Yamamoto, and Y. Tashiro. 1994. Microsomal aldehyde dehydrogenase is localized to the endoplasmic reticulum via its carboxy-terminal 35 amino acids. J. Cell Biol. 126:1407-1420.

34. Gonzalez, C. B., C. E. Caorsi, C. E. Reyes, S. Troncoso, and V. Barra. 1994. Identification and purification of vasopressin receptor from rat liver membranes. Ann. NY Acad. Sci. 689:526-529.

35. Dohlman, H. G., M. G. Caron, A. DeBlasi, T. Frielle, and R. J. Lef kowitz. 1990. Role of extracellular disulfide-bonded cysteines in the ligand binding function of the $\beta$ 2-adrenergic receptor. Biochemistry. 29:2335-2342.

36. Pathak, R. K., R. K. Merkle, R. D. Cummings, J. L. Goldstein, M. S. Brown, and R. G. W. Anderson. 1988. Immunocytochemical localization of mutant low density lipoprotein receptors that fail to reach the Golgi complex. J. Cell Biol. 106:1831-1841.

37. Doi, T., R. S. Molday, and H. G. Khorana. 1990. Role of the intradiscal domain in rhodopsin assembly and function. Proc. Natl. Acad. Sci. USA. 87:49914995.

38. Sung, C. H., B. G. Schneider, N. Agarwal, D. S. Papermaster, and J. Nathans. 1991. Functional heterogeneity of mutant rhodopsins responsible for autosomal dominant retinitis pigmentosa. Proc. Natl. Acad. Sci. USA. 88:88408844.

39. Nathans, J. 1992. Rhodopsin: structure, function, and genetics. Biochemistry. 31:4923-4931. 